Vol. 6, No. 1, 2020

Iryna Dyda

\title{
UKRAINIAN IDENTITY IN BUILDINGS OF IVAN LEVYNSKYI'S COMPANY
}

\author{
Associate professor Department of Design and Architecture Fundamentals \\ Lviv Polytechnic National University, Lviv \\ e-mail: irdyda@gmail.com \\ orcid: 0000-0002-0010-0904
}

Received: 26.05.2020 / Revised: 31.05.2020 / Accepted: 31.05.2020

(C) Dyda I., 2020

https://doi.org/10.23939/as2020.01.032

\begin{abstract}
The diversity of styles of the architectural environment at the outset of the 20th century gave a unique possibility to express the national identity of a building in its forms and details. The Ukrainian identity was not only present in the buildings of the Lviv but also equally competed with other styles, thanks to the creative methods of interpretation of compositional solutions that were traditional for the Ukrainian architecture and design, implemented by the company of Ivan Levynskyi. Buildings designed and constructed for the Ukrainian community contributed greatly to the preservation and purposeful formation of the Ukrainian architectural image of Lviv. They present a valuable foundation for the creative rethinking and use in conditions of the current architectural process in Ukraine.
\end{abstract}

Key words: Ivan Levynskyi, Ukrainian architectural identity, Ukrainian Art Nouveau architecture.

\section{Problem statement}

The modern architecture, including the Ukrainian one, pays more and more attention to the search and materialization of its own regional identity. Such priorities as conformity to standards, uniformity, savings at the cost of aesthetic qualities are now far back in the past. Researches in the sphere of psychology and sociology unanimously prove that architecture has a great ideological and socially oriented educative potential. To develop this potential, the architecture must be not only functional but also attractive both for the local people and for those visiting the country as tourists (Dyda, 2016). Usage of respectively tailored traditional regional characteristics in the modern architectural environment promotes the psychological comfort of dwellers, since the aesthetic principles of the architectural composition become more understandable and close for them, as well as increases the touristic attractiveness of the locality since guests can familiarize themselves with new architectural characteristics that are unknown in their home countries. At the beginning of the 20th century, at the initiative and with the active participation of Ivan Levynskyi's company, buildings with the Ukrainian architectural identity were designed within the framework of the new Secession style in Ukrainian cities, including Lviv. Today, these buildings have a great ideological, educative, and mental significance for us. They prove that the Ukrainian architectural tradition has a wide array of peculiar features and tools that can become a basis for the revival of the identity in the current architectural environment in Ukraine. This research is aimed at the search of the creative methodology of expression of the Ukrainian architectural identity based on the analysis of architectural features of the most famous buildings in the style of the Ukrainian Art Nouveau erected by Ivan Levynskyi's company in Lviv.

\section{Analysis of recent research and publications}

The research is based on works of scientists on a great variety of topics. The biggest group of sources is represented by papers dedicated to the life and work of Ivan Levynskyi and the operation of his company. These 
papers include in particular art researches of peculiarities of the artistic and constructive design of the most famous buildings projected and implemented by Ivan Levynskyi's company (Noha, 1993; Zuk, 1996; Slobodyan, 2007). Partially connected with these sources are the academic works devoted to the study of architectural processes in Ukraine and in Lviv in the early 20th century and, among others, the analysis of the architectural heritage of the Ukrainian Art Nouveau (Sichynskyi, 1956; Chepelyk, 2001; Tymofiyenko, eds., 2003; Biriuliov, ред., 2008; Barytskyi, 1917), as well as the study and analysis of separate monuments of architecture and art of the early 20th century - carriers of the Ukrainian identity. The social significance of preservation of the Ukrainian identity in the architecture and art is also evidenced by the recently published profound research of works of the Ukrainian modernist M. Sosenko (Cherkes, Radomska, 2019). Another group of researches is related to the role of the architecture in the life of the society: the idea of the national identity in the architecture (Cherkes, 2008), its reflection in the architectural environment of Lviv positioned as an architectural presentation of the cultural polyethnicity (Cherkes, Linda, 2016), the notion of the architectural attractiveness (Dyda, 2016). Such source base provides the required preconditions and materials for the further analysis and confirms the current significance of the selected topic of the research.

\section{Objective of the article}

The purpose of the research is to study the main tools of expression of the Ukrainian identity using the example of buildings erected in Lviv in the early 20 th century by the company of an architect, entrepreneur, and professor of Lviv Polytechnic University Ivan Levynskyi in the context of the general form-building experience of the Ukrainian Art Nouveau. Ivan Levynskyi and his colleagues managed to create avant-garde buildings equipped with the newest technical facilities that corresponded to the current European architectural fashion and at the same time stayed deeply traditional and purely Ukrainian. The research is carried out by methods of analysis and comparison of architectural features of Lviv buildings of Ivan Levynskyi's company being the carriers of the Ukrainian architectural identity. The tasks of the research: analysis of social and artistic preconditions of the appearance of the most famous monuments of the Ukrainian Art Nouveau in Lviv; identification of peculiarities of expression of the Ukrainian image of buildings in conditions of the architectural environment of Lviv of the early 20th century; study of creative methods and tools of development of the Ukrainian architectural identity within the frameworks of the style; generalization of the creative experience of Ivan Levynskyi's company in the context of his role in formation of the national identity of the modern architecture in Ukraine.

\section{Results and discussions}

In the early 20 th century, a new creative trend of European architecture appeared based on the interpretation of traditional peculiarities of the popular construction of various countries and nations. This tendency was also present in the Ukrainian national culture that became the primary source for the creation of a large group of buildings in the style of the Ukrainian Art Nouveau (Chepelyk, 2001). A peculiar circumstance of origination and development of this style was the fact that the state authorities did not provide any economic or ideological support since both parts of the Ukrainian territory were included in the Russian and AustroHungarian Empires. Buildings with the Ukrainian motifs were often perceived not only as pieces of architecture but primarily as a manifestation of the existence of Ukrainians and Ukraine, i.e. had a political implication. V. Sichynskyi draws attention to the fact that revival of the Ukrainian style to a large extent became possible owing to the development of social attitudes supporting the idea of the Ukrainian identity (Sichynskyi, 1956, p. 157). In particular, in 1898, the Society of Supporters of the Ukrainian Art was established in Galicia. According to V. Sichynskyi, "revival of the Ukrainian architectural style in the first two decades of our century gained such momentum and distribution that almost all architects practiced in this nation-wide trend. This vivid movement was independent of former state borders" (1956, p. 160).

In contrast to other architectural styles that spontaneously reflected the Ukrainian identity in the historical past, in particular, in times of the Kievan Rus or Hetmanate of the 17 th century, buildings of the Ukrainian Art Nouveau were the result of the deep analysis and generalization of the Ukrainian architectural heritage. V. Chepelyk states that the theory of the new Ukrainian style was born in discussions between architects. These are the main problems that became the subjects of discussion: the right to the creative activity within the framework of one's own style; peculiarities and originality of the Ukrainian architecture; interconnection of the 
past and the present; professional quality and artistic aspects of the new Ukrainian architecture; prospects of development and the future of the Ukrainian architectural identity (2001, p.47). A significant contribution to the theory of a new style was made by O. Slastion. He outlined the principle that is also relevant to modern architecture. The principle says that we need to look ahead, not behind and that the fundamentals of the national architecture should be old and traditional, but their comprehension and use must always be up-to-date. O. Slastion theoretically substantiated and initiated the use of ceramics for decoration of Ukrainian art nouveau buildings; he emphasized that this material has old and rich traditions of use in the whole territory of Ukraine and corresponds to aesthetic perceptions of the people and local climatic conditions. Thus, he promoted a separate direction of the use of the decorative ceramics in the architecture that was actively supported by Ivan Levynskyi. Levynskyi's company developed its own vision and methodology of interpretation of traditional features of the Ukrainian architecture in newly constructed buildings. The primary source was first of all represented by the folk architectural tradition developed in the territory of Western Ukraine. However, Ukrainian architects of Galicia faced a task that was rather difficult in the ideological and political aspects. A house in the Ukrainian style build in Lviv had to: a) have characteristic traits of the Ukrainian architecture traditional for ethnographic regions of Western Ukraine in order to make the image of a building visually familiar and "native" for the local Ukrainian community; b) underline the ethnocultural unity of Galicia with other Ukrainian regions via some characteristics that are common for the whole Ukrainian traditional architecture; c) identify the difference of the Ukrainian style of the architectural image from the style from Zakopane which was also widely used in the Ukrainian architecture of that time and had many traits in common; d) express the functional purpose and cultural and emotional priorities of the community, for which the house was built, via the visual image of this house. All these factors and circumstances also impacted the architectural design of buildings erected by Ivan Levynskyi's company in Lviv.

It It is interesting to trace the impact of the competition on the part of Zakopane style on the architectural decoration of Ukrainian-style buildings in Lviv. The primary source of it was represented by the wooden architecture of the Gorals - indigenous dwellers of the Polish part of the Carpathians, while the Guzul art, also born in the Carpathians, served as a source of form-shaping and decoration of the Ukrainian Art Nouveau. Due to equal geographical and climatic conditions, the folk architecture of the Gurals and the Guzuls had many traits in common. Among them - high steep roofs, porches with carved supporting structures, carved decoration of facades, and their details. Therefore, to achieve a visible visual difference between the Secession buildings erected in Zakopane and Guzul traditions only with the help of interpretation of three-dimensional characteristics of the folk primary source was very difficult. The difference at the level of ornaments, colors, small details was the most visible. Therefore, Ivan Levynskyi paid great attention namely to the study, analysis, and interpretation of details of decoration and ornamental motifs. O. Noha wrote about the difference between the Gural and the Guzul decorations: "... the difference between these two ways of decoration is that the Guzul method does not use any floral motifs and is expressed primarily via the geometrical ornament, while Zakopane style often uses curved lines and floral images...” (1993, p. 51) Therefore, Ivan Levynskyi's company accentuated geometrical motifs of the ornament in the decoration of Lviv buildings that were inherent to the West-Ukrainian folk art, and the Guzul art in particular. An important role in the image of the building was also played by the traditional local coloristic.

One of the methods of accentuation of visual characteristics of the environment, common for all ethnographic regions of Ukraine, was the decoration of windows on facades of Lviv buildings in the Ukrainian style. Made of colored ceramic riles, it greatly resembles traditional Ukrainian embroidered rushnyks (ritual cloth) used for decoration of icons, pictures, windows. According to V. Chepelyk (2001, p. 180), namely the laconic and monumental image, the vibrant and harmonious local charm of these rushnyks allowed them to become the main accents in the composition of facades of the sacristan's dormitory (Fig. 1) and some other Lviv Secession buildings in the Ukrainian style (Fig. 2).

In order To understand the methodology of the formation of the Ukrainian identity in the works of Ivan Levynskyi, first of all, we need to pay attention to public buildings. The public function of a building envisages the availability of a broad circle of people impacted by its architectural design, artistic image, and content richness. Public buildings are primarily located in the central part of the city, its architecture is visually available for a large number of people - local ones, visitants, those having some dealings in the house or those just passing by. Therefore, namely public buildings bear the main responsibility for the development of the architectural identity of the city. A great merit of Ivan Levynskyi's company is the introduction of the Ukrainian identity into the general multicultural (Cherkes, Linda, 2016) architectural environment of central streets of Lviv. 


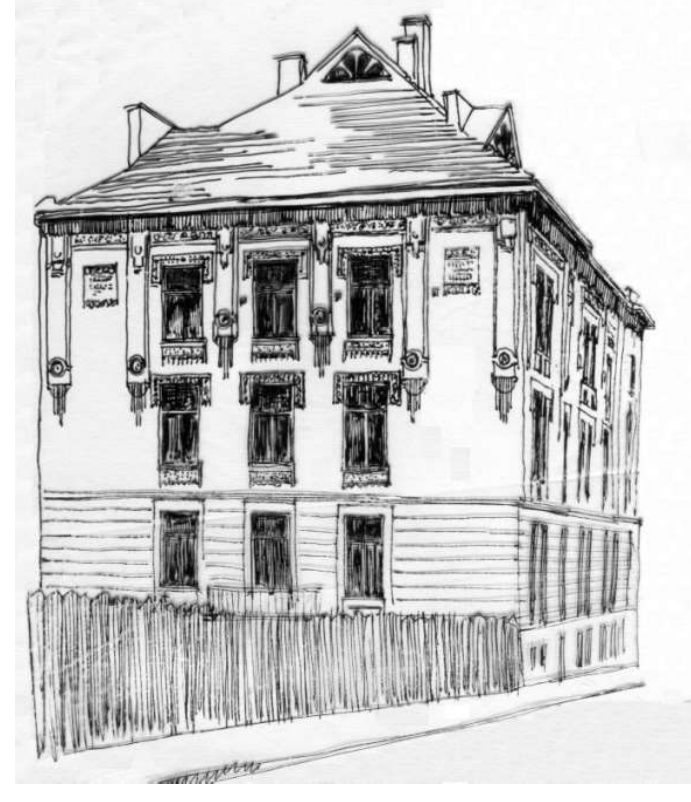

Fig. 1. Sacristan's dormitory

in the early twentieth century (author's own drawing)

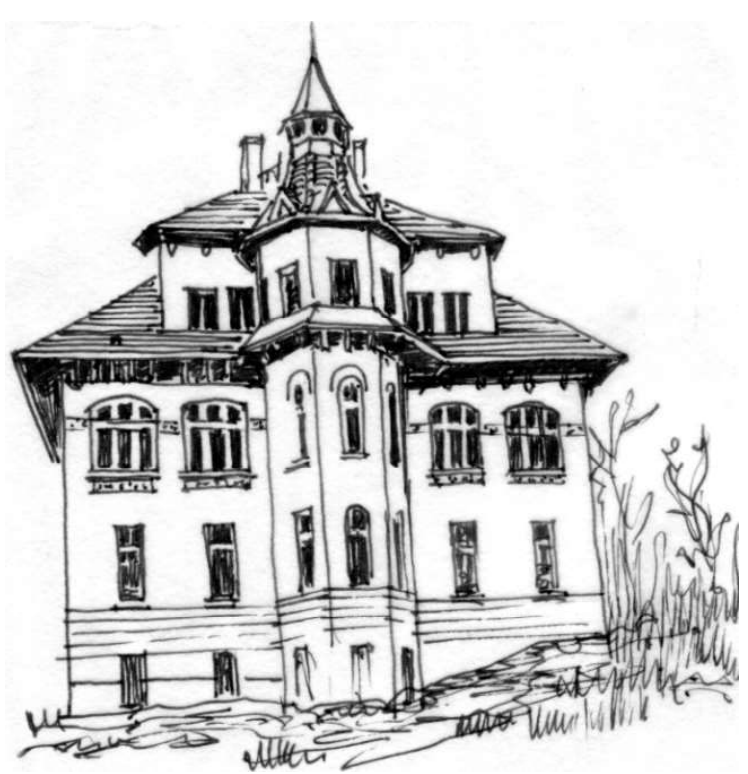

Fig. 2. Ceramic decor at the building of K. Soletsky's sanatorium (author's own drawing)

Among public buildings designed and built by Ivan Levynskyi's company in Lviv, the majority of researchers unanimously single out the building of Dnister Credit Company (Fig. 3) and Bank and the dormitory (bursa) of the pedagogic society. Describing the architectural decoration of these buildings, V. Sichynskyi notes that Levynskyi “... tried to add the traits of the Ukrainian style by decorating buildings with some ornamental motifs and details taken from the Byzantine and Ukrainian art and the folk art" (1956, p. 156). In his turn, V. Chepelyk named the building of Dnister Credit Company and Bank "one of the most essential examples of the Ukrainian Art Nouveau in Lviv" although he considered its decoration to be slightly overloaded. He saw the Ukrainian identity not only in the external shapes of this building but also in the characteristic planning and dimension inherent to Ukrainian monumental buildings (2001, p. 289; p. 182; p. 183).

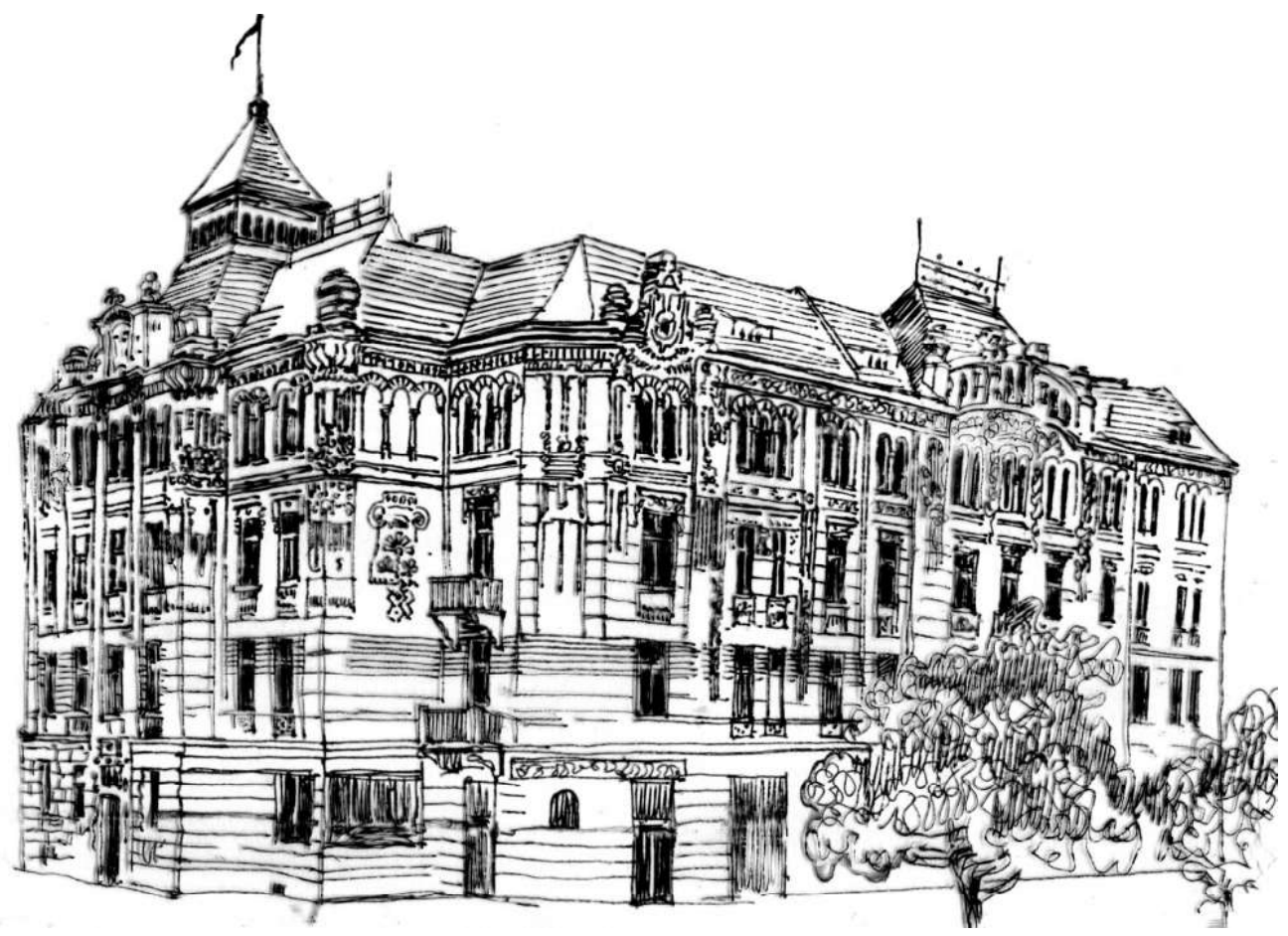

Fig. 3. The building of Dnister Credit Company (author's own drawing) 
Dnister building has four stores and occupies a visually important position at the street corner in the traditional Ukrainian historical part opposite to the Renaissance Assumption Church. It was built for the main representative office of Dnister Insurance and Credit Company - a leading financial institution in pre-war Galicia. Along with Ivan Levynskyi, the works over Dnister building were also performed by Tadeusz Obmiński (architectural design of facades), Oleksandr Lushpynkyi (polychrome majolica decoration) and Filemon Levytskyi (engineering and construction works) (Zuk, 1996). They all had a complex task: to integrate the building into the historical environment, to reflect its Ukrainian nature in its architecture, and to demonstrate the progressiveness and economic success of the customer. A land plot with a complicated location and configuration was planned out by Levynskyi based on the principles of the "rational plan". A system of internal premises grouped around the main courtyard, convenient location of internal yards, staircases and corridors ensured the efficient operation of the building. Its main function was also expanded by the cultural and educative, trade, sport, and residential functions. The building had a small hall with a scene, premises for the Ukrainian public organizations, shops, sports gym of Sokil Sports Society (Biriuliov, eds., 2008, p. 419). A big role in the image of Dnister building is played by the expressive silhouette of the steep roof inspired by shapes of the folk wooden architecture. Ukrainian motifs, stylized Guzul ornaments are used in the plasterwork and ceramic veneers of Levynskyi's factory, metal decorations, carved wooden details. Majolica facade paintings were made based on the Guzul coloristic (Zuk, 1996, p. 8). As a result, Lviv architectural environment was enriched by "a silhouette with echoes of traditions of the folk Carpathian architecture... and a wall profusely decorated with plasterwork and majolica with the coloristic impact of the Guzul ceramics spectacularly proved the birth of the modern Ukrainian nationally oriented architecture in Galicia" (Tymofiyenko, eds., 2003, p. 357).

Another famous work of Levynskyi's company - the dormitory (bursa) of the Ukrainian Pedagogic Society in Lviv - was also positively assessed by the architectural historians. In particular, V.Tymofiyenko accentuated the unique character of this building pointing out at the wide spectrum of tools of imaginative interpretation of facades. Thus, the main facade is created based on a combination of art nouveau principles with folk Guzul art traditions, while the architectural design of the back facade is inspired by the folk architecture of Dnieper Ukraine (Naddnipryanshchyna) with its white walls and "khata"-form roofs. Such a combination of regional traditions "... added traits of elegance, spirituality, and national unity into the composition of the building” (Tymofiyenko, eds., 2003, p. 349). The Ukrainian Pedagogic Society operated in Lviv since 1881, popularizing education among the Ukrainians of Galicia. The Society built dormitories (bursas) for young people willing to study in Lviv. In 1905, it announced a contest for the design project of a new dormitory. The contest was won by Levynskyi's architectural bureau (authors - Tadeusz Obmiński and Lev Levynskyi). Due to the lack of public funding, the continuation of the building process was at risk. Its successful completion became possible owing to the patronage and responsible civic position of Ivan Levynskyi who provided his own land plot for a token fee and the Metropolit Andrei Sheptytskyi who donated a half of the sum required for construction. Opposite to previous buildings of the "ornamental period" designed by Ivan Levynskyi's bureau, the dormitory of the Ukrainian Pedagogic Society belongs to the rational art nouveau and is almost deprived of the secession decorations except for pediment shapes and majolica architraves on the central avant-corps. However, as V.Slobodian notes, following the customer's request to use the Ukrainian folk shapes in the design of the building, the authors managed to strictly adhere to the Ukrainian traditions: the building has light white walls that contrast with high, visually active roofs with kinks and tops, and its monumental and at the same time laconic shape harmoniously fits into the landscape environment (2007, p. 32).

A peculiar option of expression of the Ukrainian identity in the architecture is represented by the building of Lysenko Music Society in Lviv. Its facades are designed in the forms that were popular in the European architecture, and its interiors are decorated in particular by paintings of M.Sosenko (Cherkes, Radomska, 2019) and have a vivid Ukrainian style.

The article of A. Barytskyi devoted to the house of the Lysenko Music Society tells us how the Ukrainian style of buildings was perceived by those who were to use these buildings and describes the moods of the 
Ukrainian community of Lviv in times of the World War One. In 1917, when this article was published, the society still hoped to build the National Ukrainian Theater in Lviv. Special leaflets were published to raise funds for its construction (Fig. 4). A. Barytskyi wrote that the building of the theater "will visually correspond to its noble purpose and will become a respectable center of Ukrainian muses"(Barytskyi, 1917, p. 222). The newly built building of the Lysenko Music Society had to temporarily perform functions of a theater (Fig. 5). The author notes its convenient location close to the center of the city and its accessibility by transport. Construction started in 1913 was finished already in the time of the war in 1916. It was the last Lviv building with traits of the Ukrainian Art Nouveau in its interior. The article says that the building was designed by "a good young architect Chervinskyi" (Barytskyi, 1917, p. 222), construction works were performed by the company of professor Ivan Levynskyi, and the engineering infrastructure was designed and built by another Ukrainian company belonging to the engineer Durbak. It should be emphasized that: "The building was designed and built in the modernist style. Electric lighting, central heating, artificial ventilation, water pipe, reinforced concrete flooring above the hall, iron roof support - all these installations correspond to requirements of the modern construction" (Barytskyi, 1917, p. 223). A big hall designed for theatrical performances was projected as a multifunctional facility: it corresponded to all operational requirements of a cinema and could be transformed into a dance hall. The main decoration with the Ukrainian motifs (large paintings by O. Novakivskyi, ornamental wall paintings of M. Sosenko, sculptural portraits made by M. Parashchuk) is concentrated in the big hall with a scene (Barytskyi, 1917, p. 225). Based on the abovecited fragments of the article of A. Barytskyi we can see the importance of buildings with the national stylistics for the Ukrainian community. The best Ukrainian artists and world-famous specialists were engaged in their design, construction, and decoration. Therefore, it is logical that these buildings, which were Ukrainian in their nature, were built in the popular Art Nouveau style with the use of the newest engineering developments and presented a worthy adornment of the city.

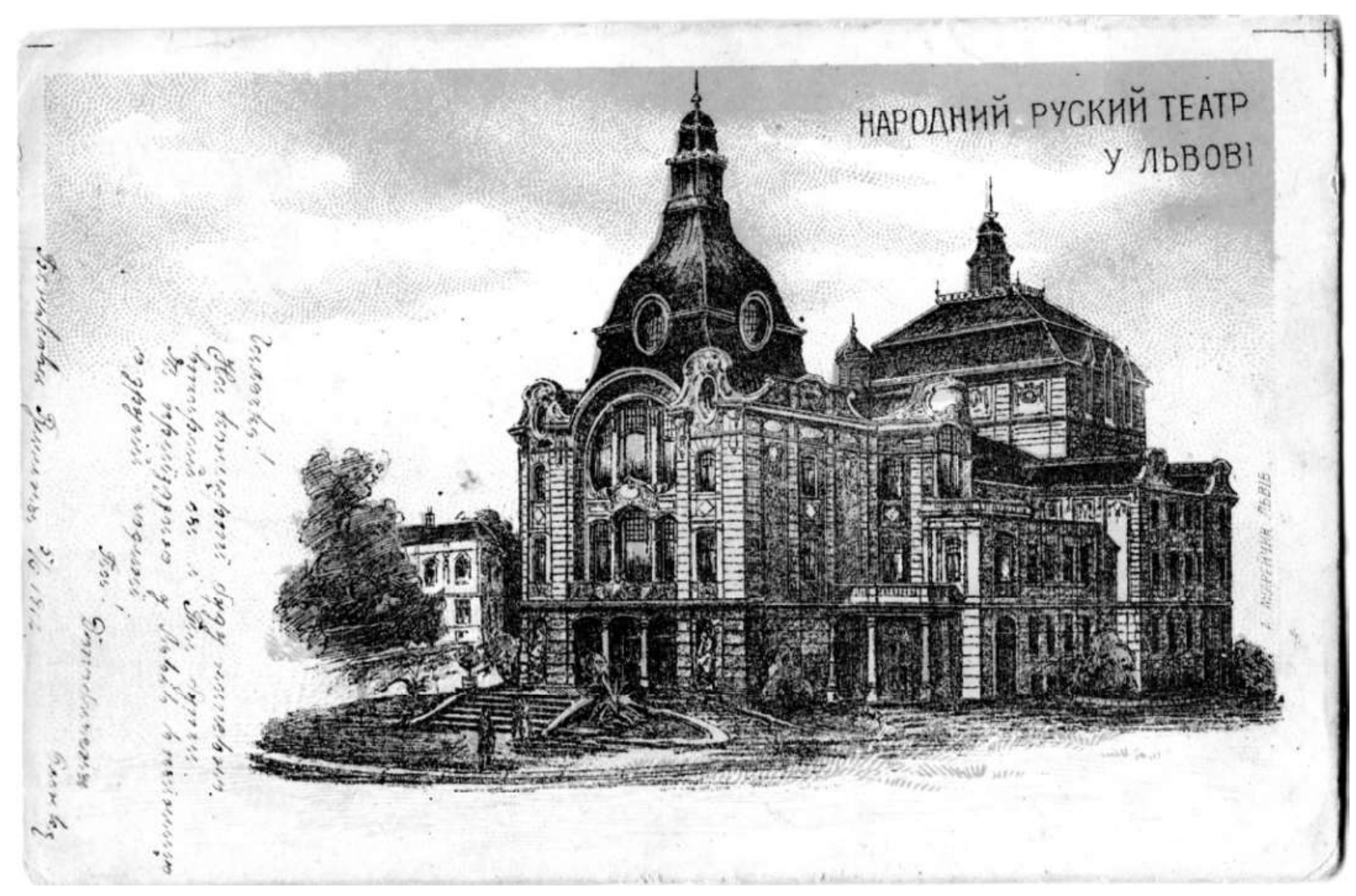

Fig. 4. Special leaflet, published to raise funds for construction of the National Ukrainian Theater in Lviv (From the private archive of the author) 


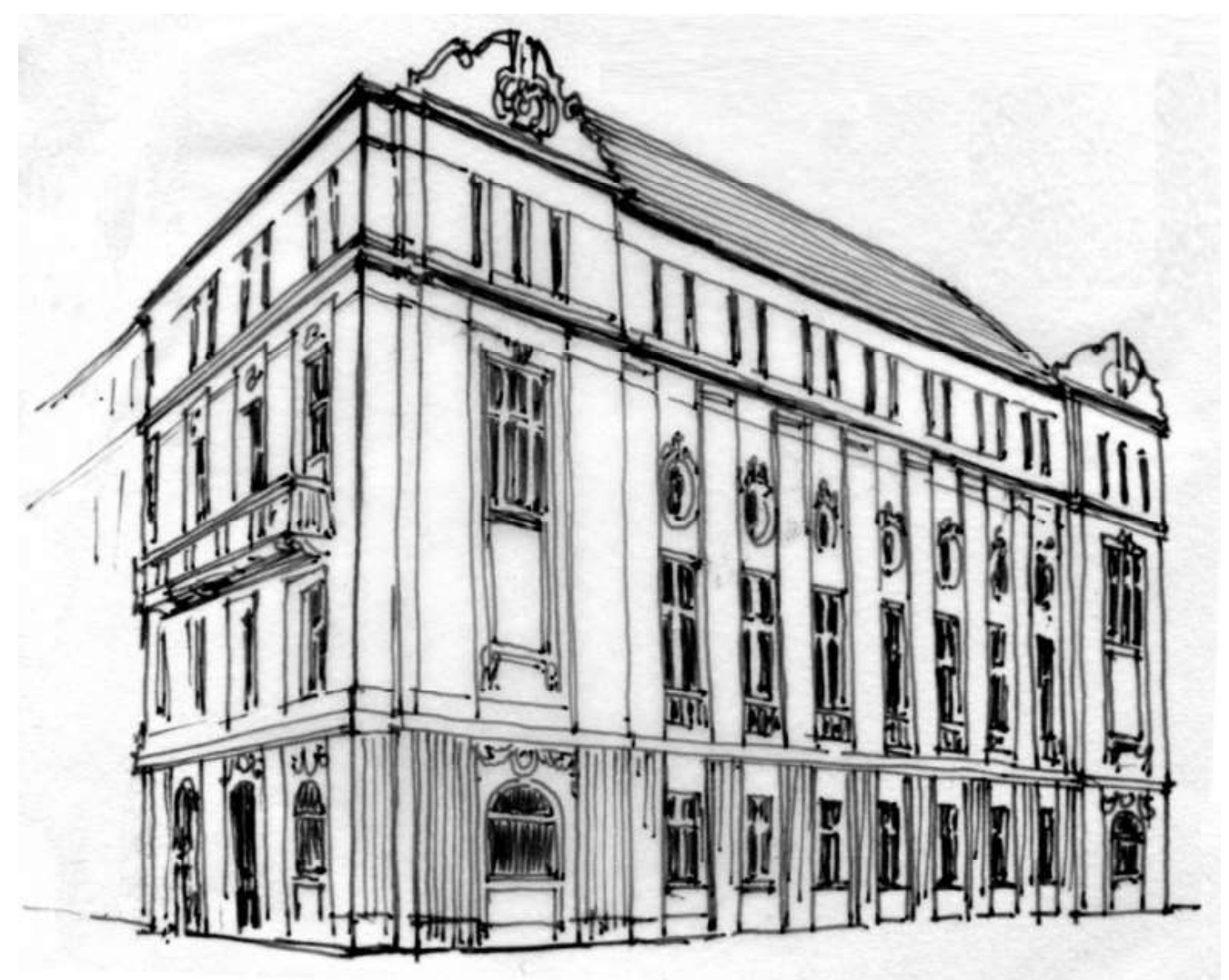

Fig. 5. The building of Lysenko Music Society (author's own drawing

The analysis of a broad spectrum of architectural methods and tools used in formation of the Ukrainian architectural identity within the framework of the Ukrainian Art Nouveau style in the whole Ukrainian territory (Chepelyk, 2001) gives a possibility to divide them into several groups: 1) reproduction of shapes of famous buildings of the ancient Ukrainian architecture, typically the wooden one, in new and more durable materials; 2) use of shapes of the Ukrainian (Cossack) Baroque, since this period is associated with the revival of the Ukrainian statehood and Ukrainian traditions in the art and architecture; 3) use of form-shaping principles traditional for the Ukrainian folk architecture: borrowing the forms of roofs and cupolas from the folk wooden architecture, including the sacral one; introduction of the color contrast of light walls with dark high roofs; 4) use of ornamental motifs of the Ukrainian folk art as an architectural decoration of facades of Secession-style buildings; 5) use of Ukrainian motifs only in the decoration of interiors.

These methods and tools could be used both on their own and in any combination in different buildings. Usually, we see the complex approach when forms of roofs typical for the folk wooden architecture are used together with the traditional coloristic and ornamental motifs in the decoration of facades and interiors. The examples of such complex use of artistic and image tools are represented, among others, by the building of Dnister Insurance Society in Lviv architecture, and the building of Poltava country council designed by V. Krychevskyi in central Ukraine. However, the Lviv School of the Ukrainian Art Nouveau has its specific peculiarities as compared to other Ukrainian creative centers of this style. In particular, the main emphasis is made on interpretation of forms traditional for the local folk construction, primarily wooden construction, and special attention is paid to Guzul art traditions and geometrical folk ornament. At the same time, as compared to other Ukrainian regions, the facades practically do not reflect the achievement of the Ukrainian (Cossack) Baroque, and the method of copying of famous Ukrainian buildings in new materials did not find a particular favor (for example in Plishivtsi village in Poltava region, where D. Yavornytskyi initiated the construction of a stone copy of the wooden nine-cupola Cossack church from Novoselytsi in Zaporizhzhia region). On the other hand, as we have already noted, there is a noticeable attempt to demonstrate the idea of the ethnocultural unity of the whole Ukraine in the architectural and decorative design of buildings of the Ukrainian Art Nouveau in Lviv and Galicia. The most vivid example of this is the building of the Lviv Pedagogic Society. Among the 
peculiar features of the use of Ukrainian motifs in the Lviv architectural environment is the widespread practice of restriction of their introduction only by interiors of public and residential buildings. Owing to the operation of Ivan Levynskyi's company, the decoration in a form of majolica ceramic tiles with motifs of the Ukrainian ornament was widely used in Lviv and Galicia in general. This high-quality decorative ceramics presented a separate element and was used in the decoration of exteriors and interiors irrespective of the specific style of the whole building.

\section{Conclusions}

Buildings of the Ukrainian Art Nouveau, including those built in Lviv by Ivan Levynskyi's company, in an ideal way, united the newest advanced functional, technological and stylistic requirements with expressed traditional visual characteristics that allow to identify them as purely Ukrainian. It became possible as a result of joint efforts of architects, constructors and the Ukrainian community of the city, their conscious desire to have, first of all, the high-quality architecture corresponding to the world standards, and, secondly, the Ukrainian architecture that would develop the ancient Ukrainian cultural traditions in new conditions.

In this context, Lviv buildings of the Ukrainian Art Nouveau are valuable for us not only as the best samples of this style but also as a positive example of the material implementation of the program of preservation and permanent reproduction of the Ukrainian architectural identity in the modern environment. In this context, we should accentuate some important aspects: 1) carriers of the Ukrainian identity were primarily represented by buildings with the expressed public function, such as financial institutions, educational establishments, hospitals, concert halls; 2) their location inside the city was convenient and compositionally attractive; 3) these buildings and even the minor parts of their decoration were designed by famous architects and artists - experts at their job; 4) the Ukrainian community formed a corresponding public demand for the Ukrainian architectural identity.

After more than one hundred years of break, the architectural activity in Ukraine found itself in conditions of the market economy without the predefined ideological dictate of state structures. The stylistics that forms the identity of buildings and the architectural environment of the city as a whole greatly depends on customer's requests and the world-view position of an architect. The Soviet approach led to irreparable losses not only in the architectural heritage but also in the attitude of the society towards it. Due to objective historically conditioned reasons, the current Ukrainian architectural realities differ from those of the early 20 th century, first of all, by a specific mental paradox: for the majority of the Ukrainian society the phrase "modern architecture" is automatically associated with foreign samples. Common "efforts" led to the disappearance of the system of stable self-reproduction of the Ukrainian national architecture typical of all other countries. At the same time, the mechanism of self-reproduction of compositionally and the philosophically alien architectural environment is actively working.

Buildings of the Ukrainian Art Nouveau, including those designed by Ivan Levynskyi's company, clearly demonstrate that the Ukrainian identity and the modern innovative architecture of the European level are synonymic notions, and both the Ukrainian architects and the Ukrainian society should perceive them in this context.

\section{References}

Cherkes,B., Linda, S., 2016. The public space and the revival of multicultural identity in the city of Lviv. Architectural Studies, Vol. 2, No. 2. Lviv: Lviv Politechnic Publishing House. C. 75-84.

Cherkes, B., Radomska V., 2019. Current state of preservation and problematic of restoring polychrome paintings by Modest Sosenko in the structure of sacred architecture. Architectural Studies, Vol. 5, No. 1, Lviv: Lviv Politechnic Publishing House. C. 1-8.

Dyda O., 2016. Importance of spontaneous attractiveness for personalization of architectural environment of Lviv region small towns (Ukraine). Recreation within a City. Hausing Environment - 17/2016.Cracow: Publication of the Chair of Housing Environment. P. 52-5.

Barytskyi A., 1917. Dim muzychnoho tovarystva im. M. Lysenka, Ukrainskyi ilustrovanyi kalendar tovarystva "Prosvita" na 1917 rik. N.40. Lviv: Prosvita. C. 222-227.

Biriuliov, J., eds., 2008. Arhitektura Lvova: chas $i$ styli. XIII-XXI st. Lviv: Tsentr Europy. 
Zuk, I., 1996. Budynok tovarystva "Dnister". Istoryko-arhitekturnyi atlas Lvova. Ser.II "Vyznachni budivli”, zoshyt 1. Lviv: Tsentr Europy.

Noha O., 1993. Ivan Levynskyi khudoznyk, arkhitekt, promyslovets, pedahoh, hromadskyi diyach. Lviv:"Osnova".

Sichynsky, V., 1956. History of Ukrainian Art, I, Architecture. New York: Shevchenko Scientific Society.

Slobodian, V., 2007. Monastyr st. Mokryny sester vasylianok. "Halyts'ka brama" No. 3-4 (147-148), L'viv "Novyy svit". S. $32-34$

Tymofiyenko, V., eds., 2003. Istoria ukrainskoyi arkhitektury. Kyiv: Tekhnika.

Chepelyk, V., 2000. Ukrayinskyi arhitekturnyi modern. Kyiv: KNUBA.

Cherkes, B., 2008. Natsionalna identychnist v arhitekturi mista. Lviv: Vydavnytstvo Natsionalnoho universytetu "Lvivska politehnika".

\section{Ірина Дида}

Дочент кафедри дизайну та основ архітектури.

Національний університет "Львівська політехніка", Львів

e-mail: irdyda@gmail.com

orcid: 0000-0002-0010-0904

\section{УКРАЇНСЬКА ІДЕНТИЧНІСТЬ У СПОРУДАХ ФІРМИ ІВАНА ЛЕВИНСЬКОГО}

Анотація. Стильове різноманіття архітектурного середовища на початку $X X \mathrm{~cm}$. сприяло демонстрачіі наиіональної ідентичності будинку в його формах і деталях. На відміну від попередніх стилів, украӥнський архітектурний модерн став результатом аналізу та узагальнення історичної української архітектурної спадщини. Фірма Левинського розвивала своє бачення і свою методику інтерпретаиії традииійних рис украйнської архітектури в нових спорудах. Значний вплив на вибір творчих засобів інтерпретачії першоджерел мали специфічні місчеві чинники $і$ обставини: споруди для української громади, поряд з традиџійними регіональними характеристиками, мали підкреслити етнокультурну єдність Галичини з рештою України, виявити стильову відмінність від “закопанського способу” у будівниитві, зазначити культурно-емоційні пріоритети громади - замовника. В иьому контексті, фірма Левинського поряд з інтерпретаиією форм народної дерев'яної архітектури, робила акиент на гуиульських регіональних мотивах в орнаментиці $і$ колористиці, $і$ на використанні кераміки в декорі фасадів. Зважаючи, що основу архітектурноі ідентичності міста формують будинки з громадською функиією, детальніше розглядаються будинки кредитного товариства і банку “Дністер”, бурси Педагогічного товариства, Українського музичного товариства ім. Лисенка, в яких проявились індивідуальні підходи до художньо-образного та архітектурного вирішення. Вони в оптимальний спосіб поєднали в собі передові для свого часу функиіональні, технологічні та стилістичні вимоги з дуже виразними традииійними візуальними характеристиками. Це стало результатом спільних зусиль архітекторів, будівельників $i$ українськой громади міста, їх усвідомленого бажання мати якісну архітектуру, що відповідала б світовим стандартам, $i$, одночасно, архітектуру українську, здатну в нових умовах розвивати українські культурні традиції. Запроектовані $i$ побудовані для української спільноти Львова споруди є иінним підтрунтям для творчого переосмислення питання украӥнської ідентичності в умовах сучасного архітектурного процесу в Украӥні.

Ключові слова: Іван Левинський, украӥнська архітектурна ідентичність, украӥнський архітектурний модерн. 